\title{
Agroecosystems, Landscapes and Knowledge of Family Farmers from Aramaçá Island, Upper Solimões Region, Amazon
}

\author{
Ayrton Luiz Urizzi Martins ${ }^{1 *}$, Sandra do Nascimento Noda ${ }^{1}$, Hiroshi Noda ${ }^{2}$, \\ Lúcia Helena Pinheiro Martins ${ }^{3}$, Elisabete Brocki4 \\ ${ }^{1}$ Faculdade de Ciências Agrárias (FCA), Universidade Federal do Amazonas (UFAM), Manaus, Brazil \\ ${ }^{2}$ Instituto Nacional de Pesquisas da Amazônia (INPA), Manaus, Brazil \\ ${ }^{3}$ Núcleo de Etnoecologia da Amazônia (NETNO), Universidade Federal do Amazonas (UFAM), Manaus, Brazil \\ ${ }^{4}$ Escola Superior de Tecnologia (EST), Universidade do Estado do Amazonas (UEA), Manaus, Brazil \\ Email: *ayrton.urizzi@yahoo.com.br
}

How to cite this paper: Martins, A.L.U., Noda, S. do N., Noda, H., Martins, L.H.P. and Brocki, E. (2018) Agroecosystems, Landscapes and Knowledge of Family Farmers from Aramaçá Island, Upper Solimões Region, Amazon. Agricultural Sciences, 9, 1369-1387.

https://doi.org/10.4236/as.2018.910095

Received: September 27, 2018

Accepted: October 28, 2018

Published: October 31, 2018

Copyright (c) 2018 by authors and Scientific Research Publishing Inc. This work is licensed under the Creative Commons Attribution International License (CC BY 4.0).

http://creativecommons.org/licenses/by/4.0/ cc) (i) Open Access

\begin{abstract}
The family farmer's knowledge about floodplains agroecosystems dynamics is part of agrobiodiversity conservation cognitive strategies. This is because the conservation in floodplains is conditioned by the ecophysiological adaptation to the period and flood gradient of the agricultural lands and by the transformations promoted in the environment by the waters pulse. The aim of this study was to understand the cognitive strategies expressed in the organized meaning of agroecosystems by local knowledge, related to the geomorphological dynamics of the Aramaçá Island, Amazonas, Brazil. In this research, the Case Study and Ethnoecology were adopted as approach, taking the systemic complexity paradigm as a theoretical framework. To do so, it was necessary to establish a dialogue with the local knowledge through multitemporal analyses of satellite images, historical series of hydrological data, as well as cartographic documents of the locality. The floodplains amphibian mark, as a living organism in permanent autopoietic process, seems to be imprinted in the family farmer's knowledge. In order to live in the floodplains and of floodplains, it is necessary, above all, to develop a cognitive ability capable of understanding not only the rivers action on the lands, but also that of the lands on the rivers as well. Therefore, the geomorphological dynamics in the spaces managed by the family farmers impose on them, risks and uncertainties, demanding from them strategies that allow knowing and dealing with this complexity.
\end{abstract}




\section{Keywords}

Geomorphological Dynamics, Ethnoecology, Floodplains, Amazonia

\section{Introduction}

Recent studies in the Brazilian Amazon have demonstrated the fundamental role of family agriculture in the conservation of agrobiodiversity, that is, in maintaining the evolutionary dynamics of cultivated species, as well as the complex agroecosystems of floodplain and "terra firme" rain forest [1] [2] [3]. The authors argue that the production strategies and techniques used by family farmers make it possible to generate a sufficient diversity of products to meet the food demands of the families, maintaining a high level of agricultural diversity, especially in the Amazonian floodplains.

In order to understand the dynamics of the floodplain agroecosystems in their complexity, it is important to consider the geomorphological processes, especially by the active river dynamics in the changes of the landscape of the floodplains. Floodplains are highly dynamic systems subject to erosion processes, transport and deposition of fluvial sediments, resulting in diverse landscapes composed of different geomorphological units [4]. The specialized knowledge shared by family farmers about the dynamics of agroecosystems is part of the cognitive strategies indispensable for the formulation of agrobiodiversity conservation strategies. This is because the cultivation, management and conservation of the genetic variability of the plant species in the floodplain agroecosystems are strongly conditioned to the ecophysiological adaptation of the species to the period and to the flood level of the arable land, as well as to the transformations promoted by the flood pulse in the environment in question [5].

This flood pulse varies slowly presenting a predictable annual cycle according to dry or rainy seasons [2]. The average length of flood depends on the precipitation, discharge and topography of the alluvial plain [6], which together with other correlated phenomena constitutes a complex process of water circulation throughout the environmental system, and enlarges the notion of flood pulse to waters pulse. The dynamics of the waters determine the morphology of the river bed and the structure of the floodplain. These processes are part of the experiences experienced by family farmers in the Solimões River floodplain, being present in each strategy of knowing and acting, integrating a specialized knowledge of the place where they live and endowing it with organized meaning [7].

The choice of the Alto Solimões microregion, Southwest Amazonian mesoregion, a triple frontier area between Brazil, Colombia and Peru [8], was due to the presence of family farms characterized by adopting forms and production techniques, whose fundamental element is the specialized knowledge about the pulse of the waters and the geomorphological dynamics of agroecosystems. Another 
aspect considered in the delimitation of the research was the study period (1973-2014) that includes extreme climatic events in the last hundred years, the two largest floods already recorded in the micro-region in 2009 and 2012, alternated by the two most intense droughts in 2005 and 2010 .

Therefore, our objective was to understand the family farmer's cognitive strategies with regard to the geomorphological dynamics of Aramaçá Island, Amazonas, Brazil. To do so, it was necessary to establish a dialogue with the local knowledge through multitemporal analyzes of satellite images, historical series of hydrological data, as well as cartographic documents of the locality.

\section{Material and Methods}

The study was carried out from January 2012 to December 2016 in São José locality, Benjamin Constant, Amazonas. The locality is part of an Agro-extractive Settlement Project, located on an island of the Solimões River with a total area of 10,781 ha known as Aramaçá (Figure 1). With geographic coordinates of $04^{\circ} 19^{\prime} 47.19^{\prime \prime}$ south latitude and $69^{\circ} 57^{\prime} 30.78^{\prime \prime}$ longitude west, São José is distant from Benjamin Constant and Tabatinga, $9.1 \mathrm{~km}$ and $10.9 \mathrm{~km}$, respective. The microregion presents a humid or superhumid tropical climate, without dry season, type $A f$ climate Köppen [9], with records of average annual temperature of $25.7^{\circ} \mathrm{C}$ and average annual precipitation of $2562 \mathrm{~mm}$, with the highest concentration of precipitations in the period between December and April [10].

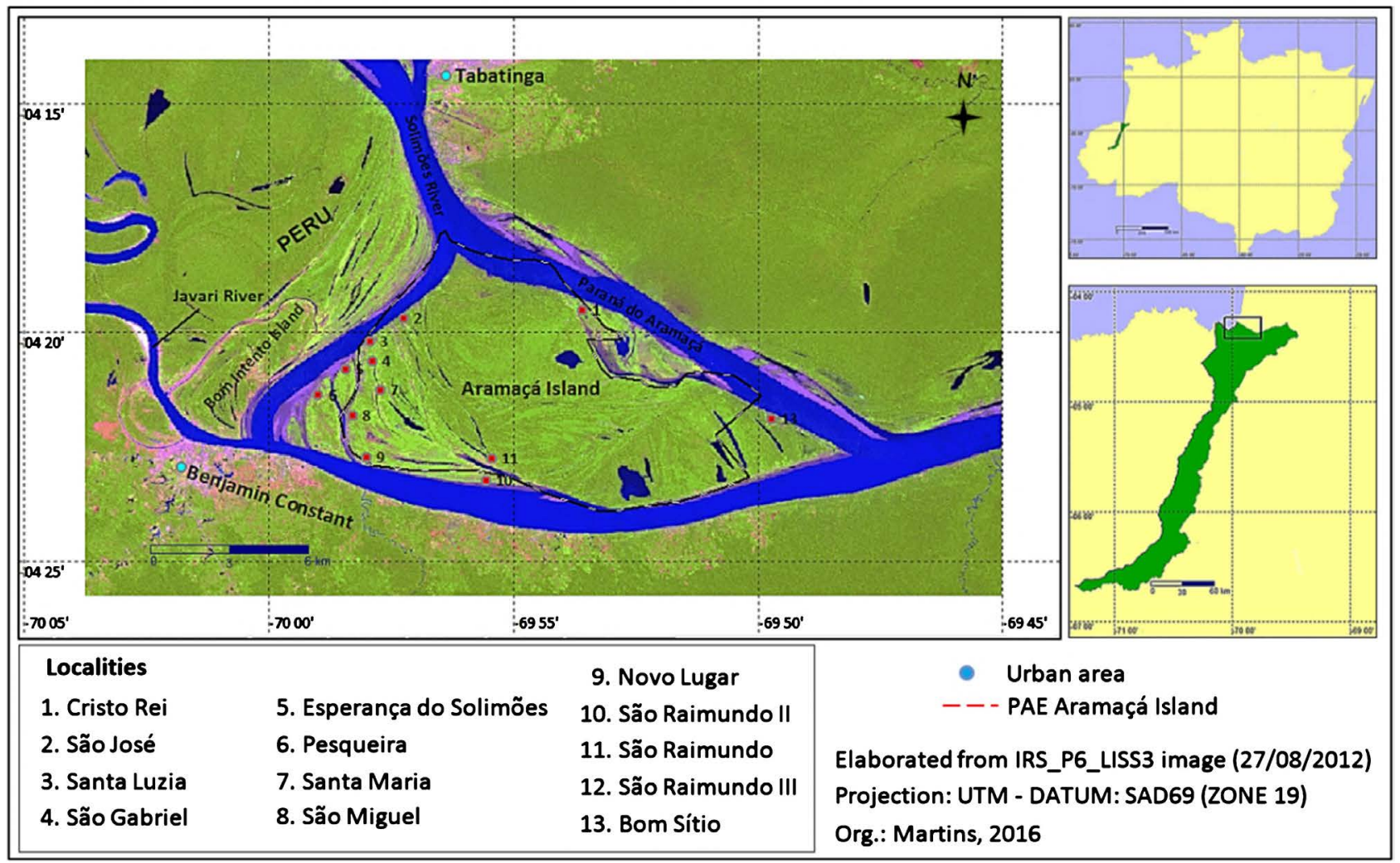

Figure 1. Study area, Aramaçá Island, Benjamin Constant, Amazon, Brazil, 2016. 
The study was based on the Multiple Case Study model [11], with the systemic complexity paradigm. As a guiding principle of the methodological strategy we used the interdisciplinary approach and the precepts of ethnoecology [12]. Dialogue with local knowledge was established through multitemporal analyzes from five satellite images (Table 1), from historical series of hydrological data, as well as cartographic documents of the locality, in a single georeferenced analytical system. In the selection of the period (1973-2012) to compose the multitemporal analyzes, the different historical events highlighted in the family farmers talks were considered, associated with the availability and quality of satellite images (low coverage of clouds). Fluviometric data from the Tabatinga Fluviometric Station obtained in the Hydrological Information System (HidroWeb) of the National Water Agency (ANA), as well as nautical charts with bathymetric survey data were considered in the methodological strategy. The images related to the studies were processed through the SPRING-DPI/INPE Georeferenced Information Processing System, version 5.2.6, in four stages: pre-processing, processing, qualitative evaluation and quantitative evaluation. It was also generated image from numerical terrain modeling (NTM) with hypsometric data obtained from the Geomorphological Database of BRASIL-TOPODATA [13]. Of the 15 family agroecosystems (FA) studied in the São José locality, representing $47 \%$ of the total, (FA01) and (FA10) were selected as references to deepen the multitemporal analyzes of the morphological dynamics of Aramaçá Island. These agroecosystems were chosen because they shelter the two oldest families in the community who still manage areas representative of those originally managed by their parents.

The Research Ethics Committee of the Federal University of Amazonas authorized the research (CAAE registration: 31704114.7.0000.5020 and Technical Advice: 732.448).

\section{Results and Discussion}

The Solimões River, when entering Brazilian territory approximately the Aramaçá Island, forks itself forming two main channels, one to the south keeping the denomination of Solimões River and another to the north denominating $\mathrm{Pa}$ raná Aramaçá. Paraná is the locally used term for the natural lateral channels to rivers in the Amazon. When reconnecting, the channels delimit the Aramaçá

Table 1. Details of acquired satellite images.

\begin{tabular}{ccc}
\hline Satellite id & Acquisition date & Spatial Resolution $(\mathrm{m})$ \\
\hline LANDSAT_1_MSS & $31 / 07 / 1973$ & 80 \\
LANDSAT_5_TM & $30 / 08 / 1984$ & 30 \\
LANDSAT_5_TM & $14 / 11 / 1994$ & 30 \\
LANDSAT_5_TM & $04 / 09 / 2003$ & 30 \\
IRS_P6_LISS3 & $27 / 08 / 2012$ & 23.5 \\
\hline
\end{tabular}


Island, of lenticular form characteristic of sedimentary plains, stretching along the stream direction [14] [15], being the product of intense erosion processes located at the upstream end, and deposition at the downstream side portions.

Aramaçá Island occupies a strategic geographical position and represents an important element in the logistics of local navigation, especially in the dry season. The river communication between Benjamin Constant, Tabatinga, Atalaia do Norte and other cities of Solimões/Amazonas channel, including the state capital, is influenced by the behavior of the insular complex characteristic of the locality, especially Aramaçá Island. The same applies to river integration with Letícia (Amazonas Colombian Department) and other locations in Peru. Through the network of channels and "paranás", it passes much of the local production and products from other localities.

The geomorphological dynamics of the Solimões River gives the Aramaçá Island a constant rhythm of transformation that leads local's farmers to call it "the island that walks". The displacement of families on the island, transferring their houses, constituting new areas of cultivation and drawing new navigation routes, are some examples of facts highlighted in the life histories of the families associated with this dynamics and delineators of the idea of an island that walks.

In the 39-year period (1973-2012), the estimate of the eroded area of the island reached 2835.74 ha, compared to 3198.93 ha of sediment deposition. This behavior of the continuous modeling process of the island's morphology was also evidenced by studies carried out in the same area from 1986 to 2006 [16] and in other localities with lowland islands in the westernmost part of Peru [17]. Figure 2 indicates the tendency of the morphology of the island to successive transformations, sometimes losing, sometimes gaining land.

Another important aspect to consider is the spatiality of processes. The island was affected by river erosion throughout its four periods analyzed and represented in the figure. However, the greatest pressure occurred at its upstream end, causing a visible flattening of the island with loss of about 1,433,60 ha of area in 39 years, resulting in the "phagocytose" of the Bruno Lake (BL) by Paraná Aramaçá, a fact that occurred between 2003 and 2012 and highlighted by family farmers. On the other hand, in the same period, the Novo Lake (NL) is formed in the northern portion of the island, in the hangover of Augusto Souza, a term used by local family farmers and conceptualized in literature [14] as a semi lentic aquatic environment formed in a depressed range bordered by "restingas".

The dynamics of lake creation is typical in geomorphological units called in the literature as flood deposits [18], whose origin is linked to the processes of filling during floods, with predominance of fine sedimentation in quiet environments, outside the influence of the channel. When analyzing each period independently, only that of 1973-1984 indicated the prevalence of fluvial erosion on sediment deposition. On the other hand, considering the four periods, both the area affected annually by river erosion and that subject to sediment deposition 


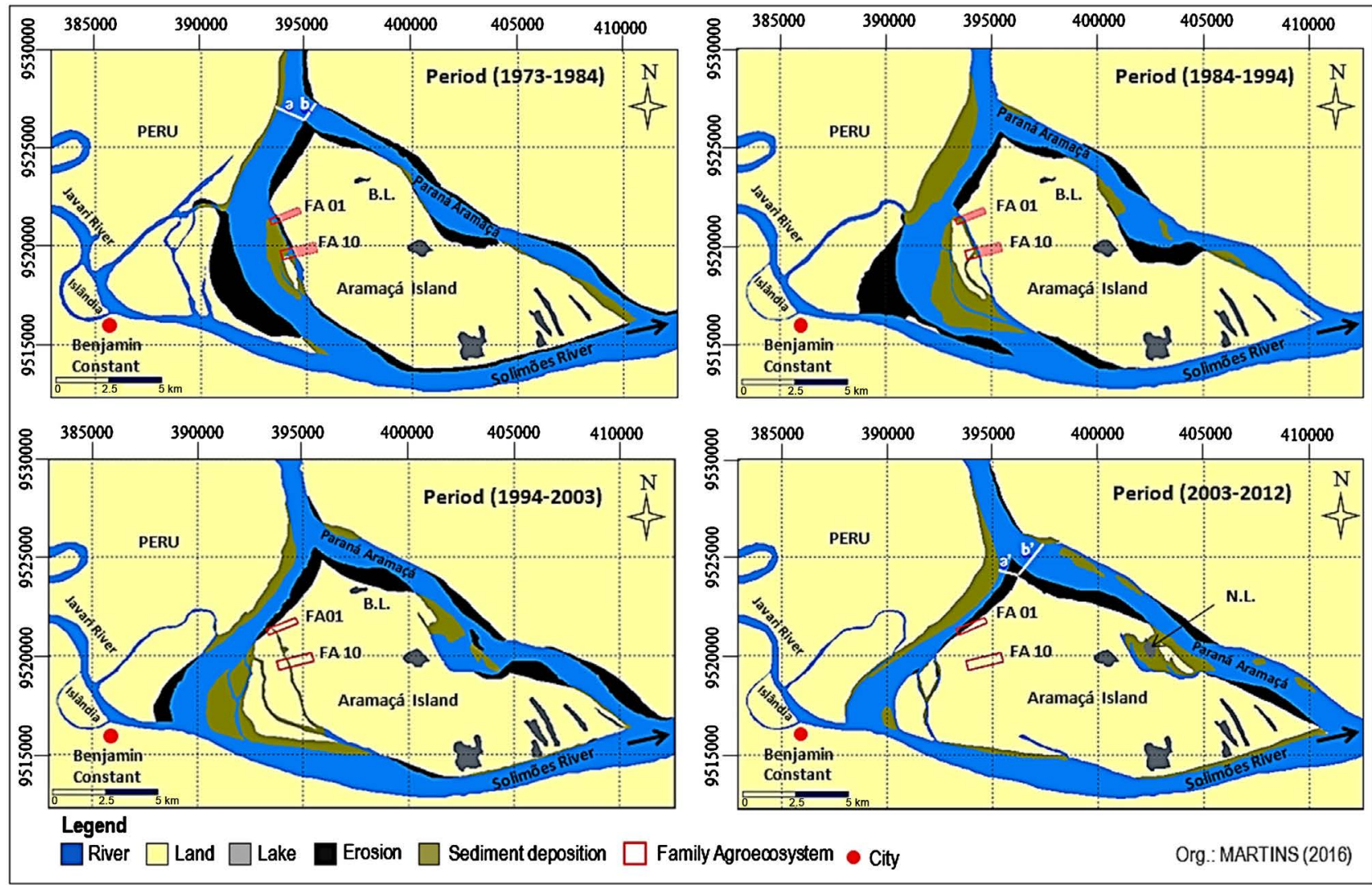

Figure 2. Multitemporal analysis of Aramaçá Island morphological dynamics, Benjamin Constant, Amazon, Brazil, 2016.

tended to remain increasing, with a moderate predominance of sediment deposition, characterizing a constructive period of the process.

Consequently, "new lands" were formed in the southwest of the island, making possible the organization of new communities from the end of the 1990s. From 1994 onwards, the predominance of erosion along the entire northern coast of the island, Paraná Aramaçá. Probably, this occurred due to the increase of water flow in the "paraná", promoting a widening and deepening of the same, a fact reported by the family farmers and confirmed by the bathymetric survey data provided by the Tabatinga Port Authority Office. In the southwest portion of the island and the Peruvian coast, bounded by the section of the channel of the Solimões River between Tabatinga and Benjamin Constant, the deposition of sediments with formation of beaches prevailed.

In 39 years, the right bank of the Solimões River, Brazil-Peru political boundary, advanced towards Aramaçá Island giving rise to an area of approximately $1723.21 \mathrm{ha}$. As a consequence, there was a narrowing of the channel in this section, going from 1541.12 to $921.32 \mathrm{~m}$ cross section, considering as reference the tip of the island upstream in 1973 and 2012, as indicated in Figure 2 in (a) and (a'), respectively. Situations such as this tend to cause elevation of the canal bottom, making the cross profile increasingly smooth [15]. On the other hand, the northern lateral portion bathed by Paraná Aramaçá became intensely eroded by 
the waters, promoting over time the widening of the "paraná", from $1136.46 \mathrm{~m}$ (b) to $1947.95 \mathrm{~m}$ (b') of cross section, considering the same period.

Because of the fluvial dynamics of the Solimões River the local population has been experiencing the migration of the main channel of the river. In turn, channel migration is related to the geometry and movement of the dunes in the riverbed. Throughout the gutter, visible in the image (Figure 3), the characteristic undulation of the fluvial dunes stands out. These contribute to the local geomorphological dynamics, influencing erosion-deposition processes, altering sediment transport rates by trawling and modifying the location of the main channel of the river [19].

In spite of the difficulty of in situ visualization, considering the amount of sediment transported by the Solimões waters, the family farmers of Aramaça Island describe this process with temporal and spatial details to the point of foreseeing, with some concern, a possible closure of the arm right in the near future.

The almost daily navigation of the river, often shared with other farmers, constitutes a rich space/moment of continuous reconstruction of the local knowledge about the dynamics of the river. The positioning of a tree at the margin, from a root attached to the river bed, from a forming point of land, from the resistance of the current to the action of the propeller of the motor of the vessel, or the alteration of the velocity of the water flow in certain parts of the river, are important signs in the day to day of those that circulate along these paths and constitute a complex local system of guidance for navigation.

The changes in the navigation of the main channel of the Solimões River are represented in Figure 4, constructed from the reports of the family farmers, data of bathymetric survey recorded in navigation chart for the year 1958 and navigation

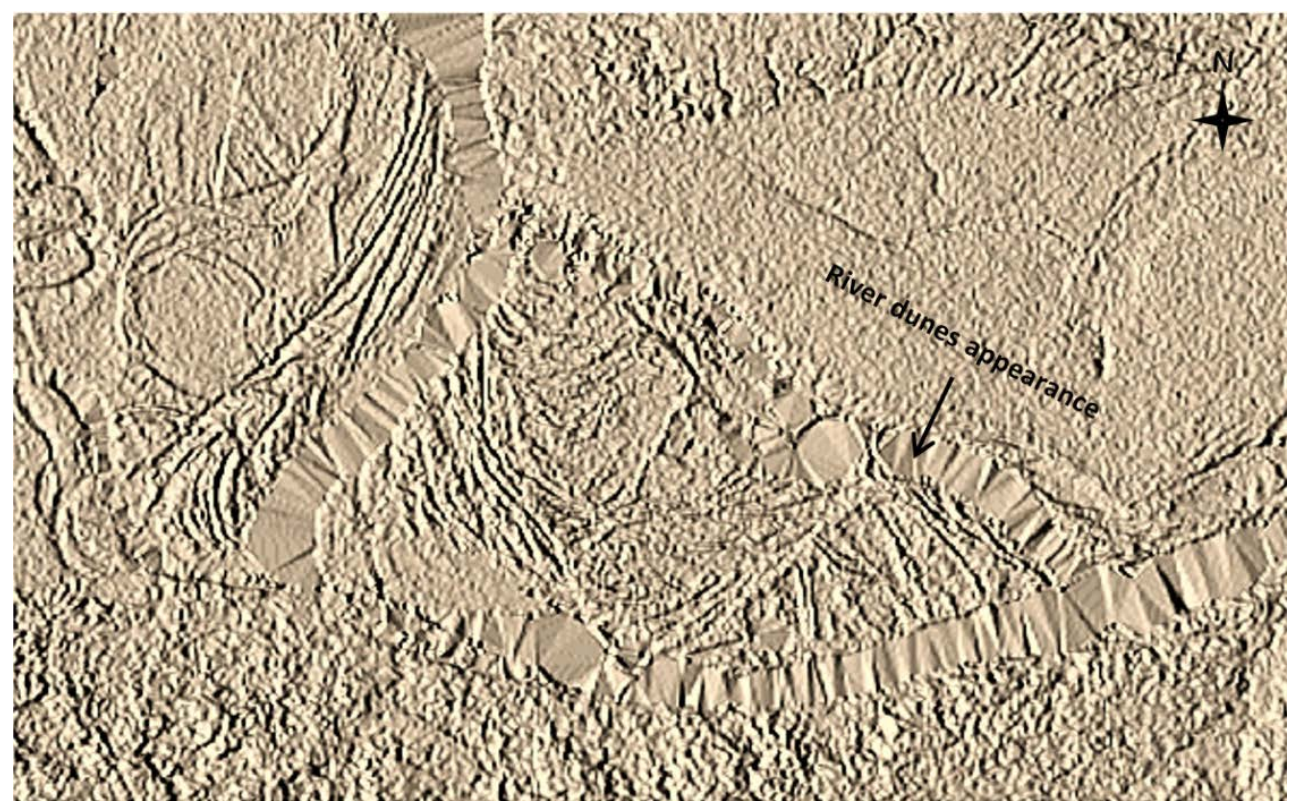

Figure 3. Solimões River bed morphologic characteristic in the surroundings of Aramaçá Island, Benjamin Constant, Amazon, Brazil. Data source: INPE (2014). Org.: Martins (2016). 


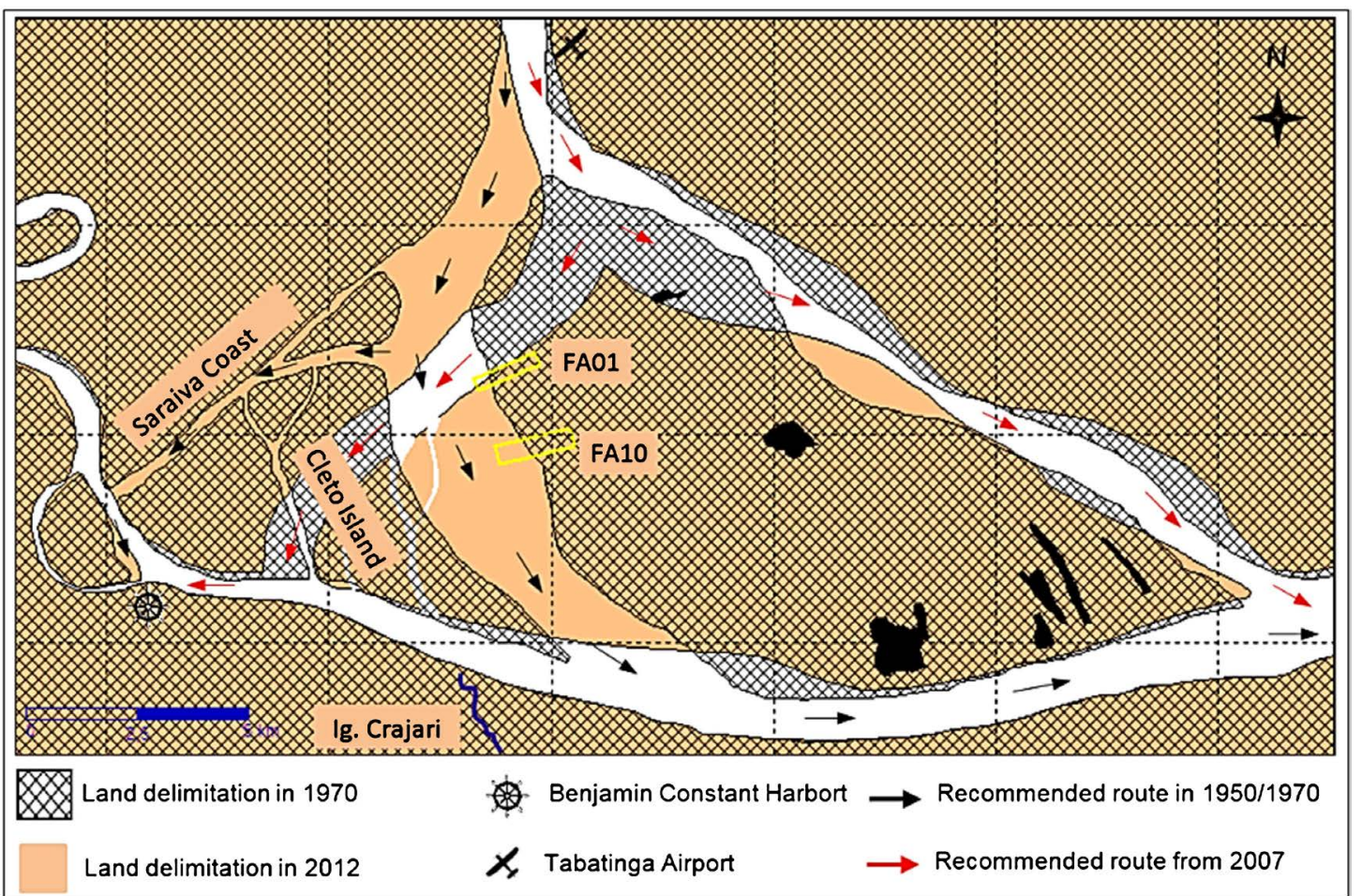

Figure 4. Comparative analysis between navigation routes recommended by the Brazilian Port Authority Office, based on data from the 1957 and 2007 bathymetric surveys. Benjamin Constant, Amazon, Brazil (Org.: Martins, 2016).

by the Tabatinga Port Authority Office. The black arrows indicate the route recommended by the Brazilian Navy to vessels of great draft until the beginning of the 1990s, following the right arm of the Solimões River and surrounding the Aramaçá Island by its southwest portion. From the first decade of 2000, the Paraná Aramaçá, left arm of the Solimões River, became the route recommended by the Tabatinga Port Authority Office for the larger vessels, indicated in red. Comparing the bathymetry data from 1958 and 2007, the mean depth of the right arm of the Solimões River in the vicinity of Aramaçá Island decreased from $16.8 \mathrm{~m}$ to $12.13 \mathrm{~m}(-4.5 \mathrm{~m})$. Meanwhile, the mean left arm depth (Paraná Aramaçá) jumped from $10.2 \mathrm{~m}$ to $14.85 \mathrm{~m}(+4.65 \mathrm{~m})$.

As shown, the fluvial dynamics of the Solimões River resulted in the migration of the main channel. Now with more depth, Paraná Aramaçá becomes the main navigation route of the great vessels in the locality. In the eyes of family farmers, the main concern concerns periods of extreme drought, as well as the future possibility of closing the right-hand side of the river, with drastic consequences for local mobility.

Until the 1970s, São José presented the land layout with the fronts positioned to the northwest and facing the river, as can be verified by the areas filled in pink of agroecosystems (AF 01) and (AF 10) (see Figure 2). In stories remembered by older residents of the São José locality, until the 1940s the Aramaçá Island lands were considered high land and only reached by the waters of the Solimões River 
eventually.

The most recent extreme floods of 2009 and 2012 are among the five largest recorded for Tabatinga/Benjamin Constant, with a maximum of $1307 \mathrm{~cm}$ and $1373 \mathrm{~cm}$, respectively. Already 2010, represents the largest drought recorded in Upper Solimões Region, with a negative dimension of $32 \mathrm{~cm}$. If the 2005 drought is considered, only in the period 1993-2012 were recorded the five largest floods and the two largest droughts for Upper Solimões Region. The greater frequency of large droughts and large floods may be correlated with the events of El Niño and La Niña [20], resulting in higher or lower precipitations, increase or reduction of river discharges and, especially, dry and flood, with many consequences for floodplain family farmers.

The arguments indicate, at least in part, the reasons why several families moved in search of new land, whether in the locality, in new lands formed contiguous to the island, or even to other localities.

There are numerous publications with reports of the damaging effect of the phenomenon of "fallen lands" in the life of family farmers [15] [21]. In turn, the phenomenon of "new lands" is little analyzed. As already mentioned, by the end of the 1970s the lands of the family farmers of São José were arranged facing the river. Now they are cut by channels that flow through the parallel sandbanks, giving the familiar agroecosystems a gentle ripple and dividing them into strips as if they were successive terraces.

From 1973 to 2012 the families (FA01) and (FA10) witnessed, for example, the expansion of their lands (see Figure 2). However, access to the river became more distant in the dry period for both, approximately $600 \mathrm{~m}$ and $1400 \mathrm{~m}$, respectively. The two subsequent periods, 1994-2003 and 2003-2012, set aside different scenarios for households. While the former was experiencing the "fallen lands" phenomenon, the latter followed its life farther and farther from the river. Now, about $1600 \mathrm{~m}$ of walk in the dry season, with serious implications for the flow of production, mobility of family members, as well as obtaining water for various purposes of use.

The pulse of the waters is thus the main driving force for most of the geomorphological processes in Aramaça Island, acting in a determinant way in the river channel morphology and in the floodplain structure. It regulates the life cycle of the local biota and, consequently, the productive activities in the familiar agroecosystems such as, agricultural cultivation, animal breeding, fishing, hunting and plant extractivism [4] [14] [22]. The data presented in the fluviogram (Figure 5) correspond to the monthly average quotas of the year 2009, 2010 and 2012, and the monthly averages referring to the historical series of 1983-2013. The two dotted cutting lines guide the delimitation of the hydrological periods for Aramaçá Island and were established based on a methodological proposal considering the historical series analyzed [23].

The pulse of the water forms four fluvial periods, popularly known as "enchente", "cheia", "vazante" and "seca", varying the months of beginning and 


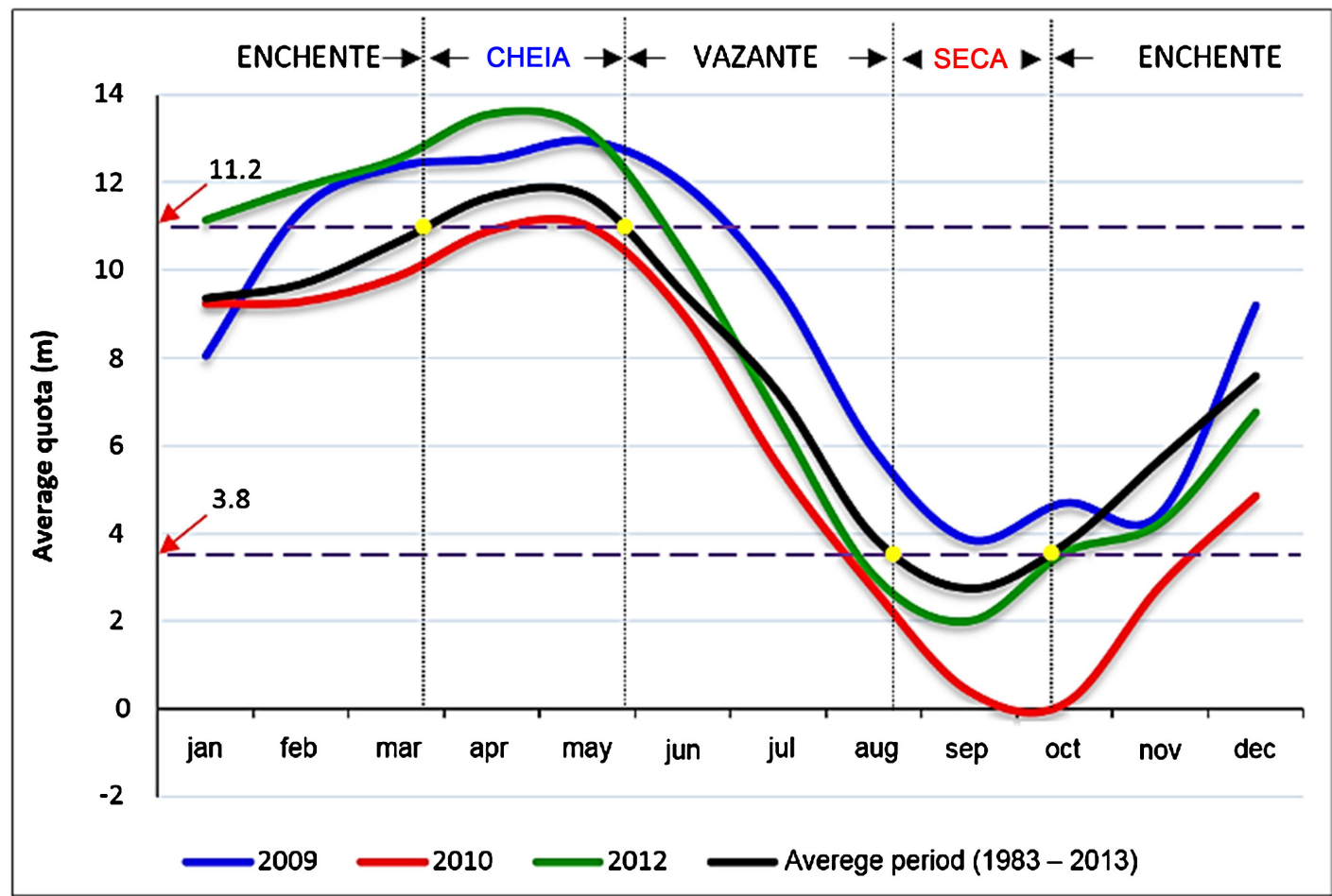

Figure 5. Solimões River regime in Tabatinga/Benjamin Constant, AM. Average of the monthly quotas recorded by the Tabatinga Fluviometric Station 10100000 (ANA, 2014). Org. Martins (2016).

ending along the gutter, as a consequence of the complex pluviometric mechanism [17], which commands the Solimões-Amazonas discharge with its various tributaries. Fluvial periods may also undergo annual fluctuations in terms of duration and intensity, requiring family farmers to adapt to the most diverse situations. The black color curve, constructed from the monthly averages of the period 1983-2013, serves as a reference to determine the typical fluvial periods, "cheia" (predominantly between April and May), "vazante" (predominantly between June and August), "seca" (predominantly in September) and "enchente" (predominantly between October and March). In the São José locality, the four periods are also differentiated, however, the denomination for them may present some variations, except for the term "seca".

Analyzing the two recent years with the highest flood ("cheias") records, 2009 (in blue) and 2012 (in green), two fundamental aspects are observed by the São José family farmers. First, the height of the water level, above normal events averages. Second, the time that soil remains flooded, reaching about five months in 2009 and 2012, while the expected one is just over two months. Variations such as these may compromise the agricultural production cycle, reducing the amount of time available to cultivation of some species, affecting the quality of the propagating material maintained for subsequent planting, and even eliminating some individuals from perennial species tolerant to seasonal flooding.

When analyzed concurrently, the fluviometric regime and the pluviometric regime in Upper Solimões Region shows simultaneity between the drought ("se- 
ca") period of the river and that of summer, different from that occurred in Central Amazonia [14]. The mean values of rainfall, mean number of rainy days per month were $11.96( \pm 4)$ days, $12.46( \pm 3)$ days and $11.77( \pm 3)$ days, respectively [10].

According to reports from family farmers, under normal conditions, even in the summer period precipitation is sufficient for the maintenance of cultivated species, reducing the work with the watering of plants. However, years of extreme drought with strict summer can result in the compromise of the production of some species less tolerant to water stress, especially the vegetables. This is because, under these conditions, access to water becomes much more difficult. The prolonged drought of the river can also have negative consequences for the flow of production, supply and mobility of families. In 2010, the drought recorded the lowest historical level, with the aggravation of prolonging the time of the river quota below $3.8 \mathrm{~m}$ for more than three months, when the normal one is little more than one month. Although the intensity of the events, both dry and full, deserving the attention of family farmers, is the duration of the events that most concern them.

For this particular aspect, family farmers usually discriminate the river regime for two periods established by the universe of work, the period with land available to the crop and the period without availability of land to the crop. The expectation of every year is to be able to count on eight to ten months of land to work. Periods far below and far above this range represent family farmers' need for adaptive strategies of work techniques and relationships.

In describing their life histories marked by profound transformations, the families of the São José Community presented, living scenarios with physical, biological and anthropogenic components interacting in time and space and constituting the landscapes of agroecosystems, not as an undifferentiated space, but rather organized, known and endowed with value, the "place" of living and working [24]. The landscape results from this "... dynamic combination of physical, biological and anthropic elements that, by reacting dialectically, make the landscape a unique and inseparable whole." [25].

The spatial variation of landscape units in agroecosystems, in turn, is subject to change every flood period, a fundamental aspect for family farmers when deciding where, when, how much and what to plant. When analyzing a landscape, both in real and from satellite images, the smallest elementary observable physiognomy corresponds to the component or unit of the landscape [26]. These units are elements whose physiognomies give information about their functionality, as well as providing indicators indicating trends in landscape dynamics. Thus, each landscape represents a percentage of constituent-composition components and a particular arrangement of components in set-configuration [22].

From the reports of the family farmers, the units constituting the landscape of the local agroecosystems and their different arrangements were identified, based on the criteria manifested by the family farmers, resulting in 12 main landscape 
units. It is worth mentioning the fact that the oldest families experienced the genesis of the southwestern portion of the Aramaçá Island, and their constituent details are still present in the environmental history of the place where they live. This aspect was fundamental for the identification of the landscape units and understanding of the dynamics of the local family agroecosystems, object of analysis to follow.

Satellite images and data from historical series on the locality were analyzed with the participation of family farmers, making possible the understanding of the original process of the parallel "restingas" to the margin of the island in the period from 1973 to 2003, also called by local family farmers of "lombos" or "lombadas". The period corresponds to the gradual local migration of the main channel of the river, which entailed the addition of alternating layers of sandy material and thinner material to the elevation of portions of earth, following the same patterns observed in other locations in the Solimões/Amazonas [14] [15]. The "restingas", when stabilizing and persisting to the pulse of the subsequent waters, began to receive the plant colonization by the ecological succession originating the new lands ("terras novas"), as can be evidenced in the discourses of local family farmers.

Family farmers describe this process in detail and even indicate the species characteristic of the initial stage of primary succession in shallow floodplain islands, such as the tacana (Gynerium sagittatum (Aubl.) P.beauv) and the embaúba (Cecropia latiloba Miq.). Tacana is a pioneer species of herbaceous habit, together with the canarana (Echinochloa polystachya (HBK) Hitchcock) and the murim grass (Paspalum fasciculatum Willd., Fluegge), the dominant pioneer species in Solimões-Amazonas of sandy soils with higher currents [27]. Embaúba, also a pioneer, is an arboreal habit species, dominant in soils with higher content of silt and tolerant to floods and sediments [28].

The predominance of sandy soils on the new beaches favors colonization by pioneer herbaceous species, providing a relative stabilization to the area and offering greater resistance to the flow of river waters [29]. Thus, thinner sediments are deposited on the beach raising the level of the same and reducing further the current in the place. This makes possible the formation of the first closed forest units, composed, mainly, by the embaúba (Cecropia latiloba Miq.). The first units create conditions for increasing the density and diversity of trees and, consequently, elevation of sedimentation rate with effects on local topography.

The geomorphological dynamics of the Solimões River influences the vegetation succession in the floodplains, creating different habitats over time. There are three important habitats in the floodplains, the high "restinga", the low "restinga" and the "chavascal", resulting from the influence of different heights and durations of the floods [30]. These habitats, in turn, present different physiognomic types of vegetation with variation in terms of composition and structure.

The term "restinga" is often used by local family farmers to differentiate higher portions of land. However, for habitat typification, it is recommended that the 
term be replaced by floodplain, avoiding confusions with the meaning of "restinga" in studies of vegetation habitats in coastal areas [29]. "Chavascal" represents a unit of vegetation of special occurrence in topographic depressions with difficulty of drainage, being influenced by the variations occurred in the water table during the whole year.

The high and low floodplain ("várzeas") differ in relation to the structure and composition of species, reflecting the topography of the environment. However, both are characterized by the dominance of typical tree species, probably because of the adaptability to flood stress [31]. In the case of low floodplain, due to the occurrence of differentiated successional stages, there are variations in terms of structure and composition of species, increasing complexity with the advancing age of the area.

Family farmers, in reporting the tree species existing on the island, also differentiate the older part of the island, high floodplains ("várzea alta"), the more recent low floodplains ("várzea baixa"), pointing to species typical of these environments and some of occurrence in both, a characteristic aspect of process of ecological succession. In referring to the species, family farmers reveal some attributes used in forest ecology studies to characterize the different ecological groups in tropical forests [31], such as wood density, tree growth rate, among others. Hardwood, in turn, is characterized by being high density, heavy and resistant much used in construction and as posts and stakes for various purposes of use.

In the hypsometric map, based on the Brazilian Geomorphometric Database-TOPODATA [13], it is possible to observe the location of the portions of land that, in the beginning, would configure the high floodplains and the low floodplains (Figure 6). The first one consists of land portions varying from 80 -

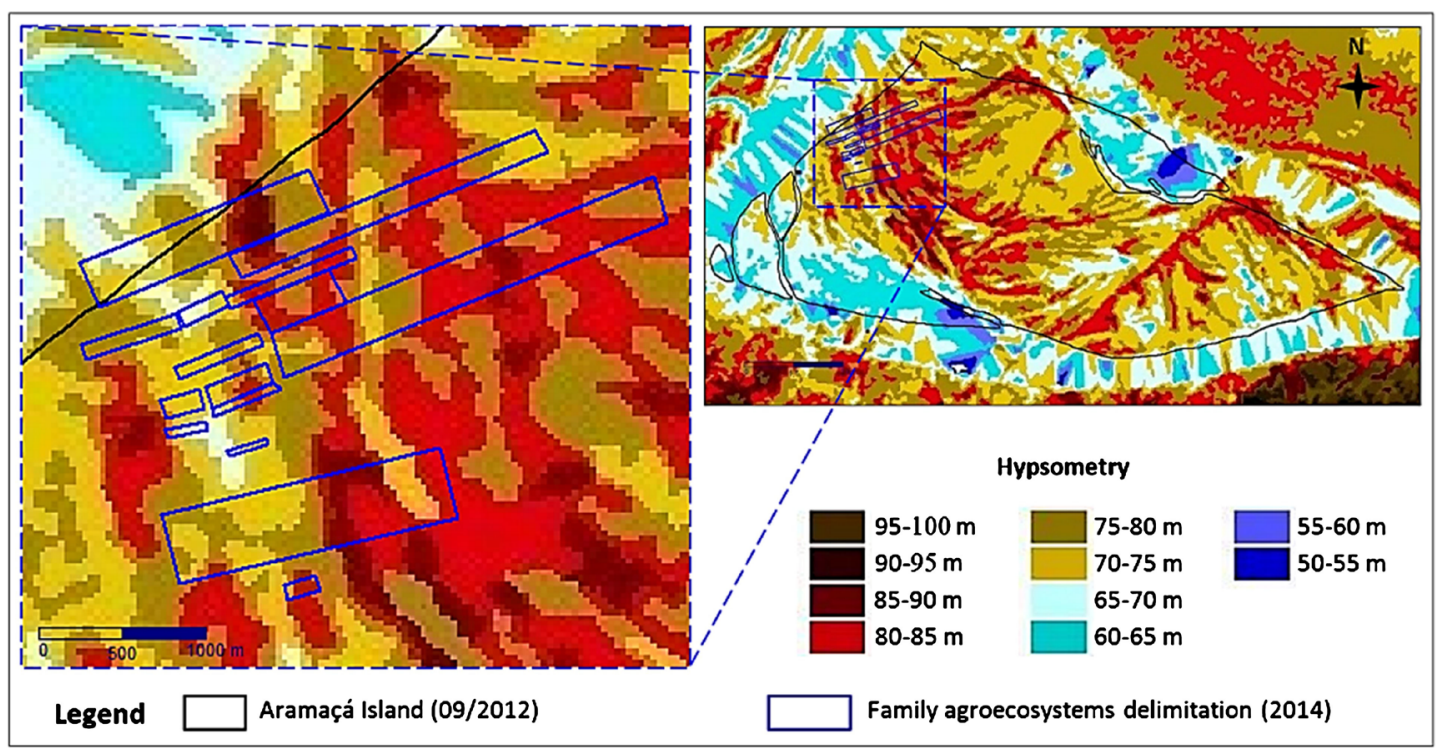

Figure 6. Aramaçá Island hypsometric map with detail in São José Locality area, Benjamin Constant, Amazon, Brazil. Data source: INPE (2014). Org.: Martins (2016). 
$90 \mathrm{~m}$ and small patches of 90 - $95 \mathrm{~m}$. According to the family farmers' information, the species louro-inamoi (Ocotea cymbarum Kunth), assacu (Hura crepitans L.), maçaranduba (Manilkara inundata Ducke) and piranheira (Piranhea trifoliata Baill), species that characterize floodplain forest in a stage of climax succession [32].

The second one comprises the lands of $70-80 \mathrm{~m}$, occurring forest species such as munguba (Pseudobombax munguba (Mart. \& Zucc.) Dugand), mulateiro (Calycophyllum spruceanum (Benth) K. Schum.), embaúba (Cecropia latiloba Miq.), limorana (Maclura tinctoria (L.) D. Don Steude), turimã (Laetia corymbulosa spruce ex Benth) and cedro (Cedrela odorata L.) characteristics of "low floodplain" in stages of initial and late secondary succession [29]. According to local information, these spaces are eventually accessed by family farmers for plant extraction and, to a lesser extent, for hunting.

Behind the "restingas" the terrain declines smoothly, delimiting lower areas, constituting the "chavascais" (class 65 - $70 \mathrm{~m}$ ) [30]. When the depression in "chavascal" is more pronounced, the "poço" [3] forms an important part of the landscape recognized by local family farmers, characterized by maintaining water depth even in the dry season. "Chavascal" and "poços" guarantee family farmers access to the water used for manual irrigation of those cultivated species most susceptible to water stress in the summer, such as vegetables.

In the detail of Figure 6, one can verify the positioning of familiar agroecosystems in the São José Locality, arranged transversely to the "restingas". These "restingas" present hypsometric classes varying between 70 - 75 m, 75 - 80 m, 80 - $85 \mathrm{~m}$ and in some points of 85 - $90 \mathrm{~m}$. The sandbank ranges are interspersed by narrow, locally called "canos" channels with a hypsometric class of $65-70 \mathrm{~m}$, fundamental to the local drainage of the land, the availability of water for various uses, the displacement of families and transportation of the community by canoe to reach the river. During the dry season of the river, this displacement and transportation are carried out by a path permanently clean and located a few meters from the "cano", parallel to it.

The hypsometric classes of $60-65 \mathrm{~m}, 55-60 \mathrm{~m}$ and $50-55 \mathrm{~m}$ delimit the lakes, fishing place, with high representativeness in the interior of the island. The family farmers of São José indicate 15 main lakes, being the fishing also realized in the river and "cano", depending on the river regime. Considering the intense dynamics of the island and the current regulation of land use in the Agroextractivist Settlement (PAE), many families cultivate their "roças" (plantations) in areas not necessarily contiguous to the lands where their houses are located. Although there is a certain understanding among family farmers about the limits of the agroecosystems of each family, it is common to have among them the transfer of areas for cultivation, a situation verified in $47 \%$ of the family agroecosystems studied.

The "roças" are located in the "restingas" constituted by the hypsometric classes of 70 - $75 \mathrm{~m}$ and 75 - $80 \mathrm{~m}$, composing different arrangements according 
to the adaptive characteristics of each species. Those short-cycle species, for example, are positioned in the lower areas, or cultivated later in higher areas. The areas of the family agroecosystems occupied by the plantations are relatively small when compared to those of "terra firme" rain forest, on average $1.3( \pm 0.7)$ ha, varying from 0.32 ha to 2.66 ha.

The houses are positioned close to the main canals occupying, as far as possible, the highest parts. However, their location follows logic of favoring accessibility to water. In the surroundings of the houses it is possible to find some fruit tree species tolerant to the periodic flood and other shrub and herbaceous of multiple uses. This space is locally referred to as a "sítio" or "quintal" and represents an important place for the conservation of multipurpose plants and the breeding of small animals. Family farmers differentiate between "sítio" and "quintal" landscape units. The occurrence of higher density of perennial consolidated species and the size of the occupied area are the main attributes of differentiation between them. Those family agroecosystems where, in the surroundings of the house, there is still diversity of tree species in different strata of the vegetation receive the denomination of the "sítio", otherwise they are called "quintal" (home garden).

"Sítios" may also occur far from home, a situation not common to "quintais". In the area of the São José locality with predominantly high sandstones, from 80 - $85 \mathrm{~m}$ and 85 - $90 \mathrm{~m}$, it was possible to find old "sítios" in 33\% of family agroecosystems, with areas varying from 1.04 ha to 2.46 ha. The "quintais" spaces ranged from 0.07 ha to 0.53 ha and were verified in $73 \%$ of the familiar agroecosystems. The tree species were still in the initial phase of growth, due to the need to renew the planting on the occasion of the damages resulting from the floods of 2009 and 2012. Although the species selected to the cultivation in the "quintais" are considered tolerant to the seasonal flood, several plants are not resisting the prolonged periods of submersion, since, at the initial stage of development, they are more sensitive.

The "capoeiras", representing fallow areas, were found in practically all family agroecosystems (80\%), varying from 0.22 ha to 3.48 ha. The fallow technique generally applies in the higher areas where the process of nutrient deposition by floods is less intense, extending for two to four years, depending on the need. The fallow is a technique of soil management used by family farmers in agroecosystems of "terra firme" rain forest and high floodplains whose main purpose is the recomposition of the soil properties after crop cycles [33]. In addition to promoting improvements in the natural fertility of the soil, other benefits result from the practice of fallow as the control of pests, diseases and invasive herbs.

Family farmers attributed other purposes to "capoeiras". The protection of the cultivated area at the entrance of the sand ("aterro") through the canal, functioning as a filter and allowing only the passage of thinner material (silt and clay) termed by the farmers by "clay". As well as the maintenance of soil moisture near the cultivated areas in the summer period. 
The "capoeira" kept at the borders of the channels acts to alter the turbulence and reduce the speed of the water when invading the "restingas" by the channels in the period of flood. This phenomenon varies from site to site and performs a work of sorting suspended material, resulting in deposition of sediments with variations in terms of granulometry [15] [34]. The retained material is characterized by a higher percentage of sand, undesirable to the farmer. On the other hand, the unretained material, with higher fractions of silt and clay, reaches the most distant portions of the channel and, when sedimented, confers better properties to the soils of agroecosystems.

The predominance of sediment deposition with different granulometries is therefore decisive in the local characterization of soil types as well as in the composition of the arrangements of the familiar agroecosystems. For the family farmers of São José there is no way to say with certainty how long a certain portion of land can be used for cultivation without interruption. The need to set up fallow or not will be determined by the yield of the last production in the area in question. Also, due to the quality of the sediments deposited by the previous flood.

If on "terra firme" rain forest the fallow period of "capoeiras" is a determinant factor to the temporal space composition of the managed areas in the familiar agroecosystems, the main differential to establish the arrangements in the floodplains of Aramaçá Island points to the time of flood and the quality of sediment deposited each year. Therefore, the maintenance of "capoeiras" represents another strategy of recursion and complementarity allowing the family farmer the use of environmental services in the environmental conservation and improvement of the soil of the arable areas.

\section{Conclusions}

In order to live in the floodplains and floodplains, it is necessary above all to develop a cognitive ability capable of understanding the river's action on the lands and recursively of the lands on the rivers. The geomorphological dynamics in the spaces managed by the family farmers impose on them, a high degree of risks and uncertainties, demanding, on the part of these, strategies that allow knowing and dealing with this complexity. Therefore, the amphibian mark of the floodplains, as a living organism in permanent autopoietic process, seems to be imprinted in the knowledge of the family farmers of São José.

In this perspective, it is relevant to consider the existence of a complex relationship between the dynamics of the floodplains agroecosystems and the strategies of conservation of agrobiodiversity. The landscape units are mutually articulated in a feedback form giving shape to the agroecosystems, so the analysis of the parts only in a segregated way becomes less useful, requiring a temporal analysis of the landscape configuration considering, in their complexity, the factors that influence these dynamics. The "way of the waters", recommended by the family farmers of the São José locality as the guiding principle of the study, 
allowing the understanding of the dynamics of the landscapes of the agroecosystems of Aramaçá Island, also revealed the cognitive strategies printed in the local knowledge, possible to be seen by the epistemological cut proposed in the paper. It is worth mentioning the fact that the oldest families have in their memories details of the environmental history of the place where they live, Aramaçá Island, a fundamental aspect for the identification of landscape units and understanding of the dynamics of local family agroecosystems.

\section{Conflicts of Interest}

The authors declare no conflicts of interest regarding the publication of this paper.

\section{References}

[1] Emperaire, L. and Eloy, L. (2008) The City, a Focus of Agricultural Diversity in Rio Negro (Amazonas, Brazil)? Boletim do Museu Paraense Emílio Goeldi. Ciências Humanas, 3, 195-211. https://doi.org/10.1590/S1981-81222008000200005

[2] Martins, P.S. (2005) Evolutionary Dynamics in Amazonian Caboclo 'Roças'. Advanced Studies, 19, 209-220.

[3] Noda, S.N., Martins, A.L.U., Noda, H., Silva, A.I.C. and Braga, M.D.S. (2012) Landscapes and Ethnoknowledge in Ticuna and Cocama Agriculture on the Upper Solimões River, Amazon. Boletim do Museu Paraense Emílio Goeldi. Ciências Humanas, 7, 397-416. https://doi.org/10.1590/S1981-81222012000200006

[4] Junk, W.J. (2000) Neotropical Floodplains: A Continental-Wide View. In: Junk, W.J., Ohly, J.J., Piedade, M.T.F. and Soares, M.G.M., Eds., The Central Amazon Floodplain: Actual Use and Options for Sustainable Management, Backhuys, Leiden, 5-26.

[5] Wittmann, F., Junk, W.J. and Piedade, M.T.F. (2004) The Várzea Forests in Amazonia: Flooding and the Highly Dynamics Geomorphology Interact with Natural Forest Succession. Forest Ecology and Management, 196, 199-212.

https://doi.org/10.1016/j.foreco.2004.02.060

[6] Wittmann, F., Schöngart, J., Montero, J.C., Motzer, T., Junk, W.J., Piedade, M.T.F., Queiroz, H.L. and Worbes, M. (2006) Tree Species Composition and Diversity Gradients in White-Water Forests across the Amazon Basin. Journal of Biogeography, 33, 1334-1347. https://doi.org/10.1111/j.1365-2699.2006.01495.x

[7] Tuan, Y. (2013) Space and Place: The Perspective of Experience. Eduel, Londrina.

[8] Brazilian Institute of Geography and Statistics. Cities@. Regional Division-Cartograms. http://www.ibge.gov.br/home/geociencias/geografia/default_div_int.shtm

[9] Alvares, C.A., Stape, J.L., Sentelhas, P.C., Gonçalves, J.L.M. and Sparovek, G. (2014) Köppen's Climate Classification Map for Brazil. Meteorologische Zeitschrift, 22, 711-728. https://doi.org/10.1127/0941-2948/2013/0507

[10] National Institute of Meteorology (2015) BDMET_Historical Data. http://www.inmet.gov.br/portal/index.php?r=bdmep/bdmep

[11] Yin, R.K. (2015) Case Study: Planning and Methods. Bookman, Porto Alegre.

[12] Albuquerque, U.P., Lucena, R.F.P. and Alencar, N.L. (2010) Methods and Techniques for Collecting Ethnobiological Data. In: Albuquerque, U.P., Lucena, R.F.P. and Cunha, L.V.F.C., Eds., Methods and Techniques in Ethnobiological and Eth- 
noecological Research, NUPPEA, Recife, 41-64.

[13] National Institute of Space Research. Geomorphometric Database of Brazil (TOPODATA). Paper Sheet 04S705. http://www.webmapit.com.br/inpe/topodata

[14] Pereira, H.S. (2007) Socio-Environmental Dynamics of the Solimões-Amazonas Floodplains. In: Fraxe, T.J.P., Pereira, H.S. and Witkoski, A.C., Orgs., Amazonian Riverside Localities. Ways of Life and Use of Natural Resources, EDUA, Manaus, 11-34.

[15] Sternberg, H.O. (1998) Water and Man in Careiro Floodplain. Emílio Goeldi Paraense Museum, Belém.

[16] Carneiro, D.S., Souza, J.C.R., Vicens, R.S. and Carvalho, J.A.L. (2009) Solimões River Morphodynamics and Social Implications: A Proposal of Environmental Education Supported by Geotechnologies and Traditional Knowledge. Brazilian Symposium on Remote Sensing, São José dos Campos, 2381-2387.

http://marte.sid.inpe.br/col/dpi.inpe.br/sbsr@80/2008/11.18.01.39.59/doc/2381-238 7.pdf

[17] Kalliola, R., Jokinen, P. and Tuukki, E. (1999) Fluvial Dynamics and Sustainable Development in Upper Rio Amazonas, Peru. In: Padoch, C., Ayres, J.M., Pinedo-Vasquez, M. and Henderson, A., Eds, Várzea: Diversity, Development, and Conservation of Amazonia's Whitewater Floodplains, NYBG, New York, 271-282.

[18] Iriondo, M.H. (1982) Geomorphology of the Amazonian Plain. Symposium of the Quaternary in Brazil, Rio de Janeiro, 323-348.

[19] Strasser, M.A. (2008) River Dunes in the Solimões-Amazonas River: Dynamics and Sediment Transport. 148 f. Doctoral Thesis, UFRJ, Rio de Janeiro.

[20] Zeng, N., Yoon, J., Marengo, J.A., Subramaniam, A., Nobre, C.A., Mariotti, A. and Neelin, J.D. (2008) Causes and Impacts of the 2005 Amazon Drought. Environmental Research Letters, 3, Article ID: 014002. https://doi.org/10.1088/1748-9326/3/1/014002

[21] Renó, V.F. (2016) Amazonian Floodplains: Landscape Changes and Their Impacts on the Provision of Ecosystem Services and Well-Being of Riverine Localities. Doctoral Thesis, INPE, São José dos Campos.

[22] Laques, A., Léna, P., Silva, A.I.C., Martins, A.L.U., Arvor, D., Dessay, N., Noda, H., Noda, S.N., Robert, P., Loireau, M. and Guillaumet, J. (2013) Public Policies and Effects on Resource Management Strategies: The Case of Upper Solimões, Amazonas, Brazil. In: Noda, H. et al., Orgs., Socioenvironmental Dynamics in Family Agriculture in the Amazon, Wega, Manaus, 7-32.

[23] Bittencourt, M.M. and Amadio, S.A. (2007) Proposal for Rapid Identification of Hydrological Periods in Lowland Areas of the Solimões-Amazonas River near Manaus. Acta Amazonica, 37, 303-308. https://doi.org/10.1590/S0044-59672007000200019

[24] Tuan, Y. (2012) Topophilia: A Study of the Perception, Attitudes and Values of the Environment. Eduel, Londrina.

[25] Bertrand, G. (2004) Landscape and Global Physical Geography: Methodological Draft. Revista Ra'e Ga, Curitiba, 8, 141-152.

[26] Guillaumet, J., Laques, A., Léna, P. and Robert, P. (2009) La spatialisation de la biodiversité: Pour la gestion durable des territoires. (Collection Latitudes). 23. IRD Éditions, Marseille. https://doi.org/10.4000/books.irdeditions.1157

[27] D’Angelo, S.A. (2009) Plant Colonization in Areas of Recent Sedimentation in the Floodplain of Central Amazonia. Masters Dissertation, National Institute of Ama- 
zonian Research, Manaus.

[28] Parolin, P., Oliveira, A.C., Piedade, M.T.F., Wittmann, F. and Junk, W.J. (2002) Pioneer Trees in Amazonian Floodplains: Three Key Species form Monospecific Stands in Different Habitats. Folia Geobotanica, 37, 225-238. https://doi.org/10.1007/BF02804233

[29] Wittmann, F., Anhuf, D. and Junk, W.J. (2002) Tree Species Distribution and Community Structure of Central Amazonians Várzea Forests by Remote-Sensing Techniques. Journal of Tropical Ecology, 18, 805-820. https://doi.org/10.1017/S0266467402002523

[30] Ayres, J.M. (1995) The Forests of the Mamirauá Floodplain: Mid-River Solimões. CNPq Mamirauá Civil Society, Brasília, 1.

[31] Kageyama, P. and Gandara, F.B. (2000) Recovery of “Matas Ciliares”. In: Rodrigues, R.R. and Leitão Filho, H.F., Eds., Riparian Forests: Conservation and Recovery. EDUSP/FAPESP, São Paulo, 249-270.

[32] Conserva, A.S. (2007) Seed Germination, Emergence and Recruitment of Seedlings of Ten Arboreal Species of the Lowlands of the Amanã and Mamirauá Sustainable Development Reserves, Central Amazonia. Doctoral Thesis, National Institute of Amazonian Research, Manaus.

[33] Noda, S.N., Noda, H. and Pereira, H.S. (2000) Family Farming Systems in the Floodplains of the State of Amazonas. In: Junk, W.J., Ohly, J.J., Piedade, M.T.F. and Soares, M.G.M., Eds., The Central Amazon Floodplain: Actual Use and Options for Sustainable Management, Backhuys Publishers, Leiden, 215-241.

[34] Wittmann, F., Schöngart, J. and Junk, W.J. (2010) Phytogeography, Species Diversity, Community Structure and Dynamics of Central Amazonian Floodplain Forests. In: Junk, W.J., et al., Eds., Amazonian Floodplain Florests: Ecophysiology, Biodiversity and Sustainable Management (Ecological Studies). Springer Science/Business Media, Netherlands, 61-105. https://doi.org/10.1007/978-90-481-8725-6_4 